\title{
Brachythecium rutabulum, A Neglected Medicinal Moss
}

\author{
Jacek Drobnik $^{1}$ (D) Adam Stebel $^{1}$
}

Published online: 6 December 2017

(C) The Author(s) 2017. This article is an open access publication

Keywords Brachythecium rutabulum $\cdot$ Rhytidiadelphus triquetrus $\cdot$ Homalothecium sericeum $\cdot$ Materia Medica $\cdot$ Dressing materials $\cdot$ Moss $\cdot$ Historical botanical nomenclature

\section{Introduction}

The search for new pharmaceuticals from naturally occurring biological materials has been guided by ethnobiological data. The investigation of folk medicine is a valuable tool in bioprospecting for pharmaceutical compounds (Costa-Neto 2002), and natural product drug development is key to the pharmaceutical industry. Over the past decade, research on medicinal plants has increasingly used historical medicobotanical texts both to study the development of pharmacopoeias as well as to identify candidate species for drug development (Staub et al. 2016).

The first medicinal bryophytes were noted in the first century and subsequently a relatively large number of species in the phylum Bryophyta have been recognized in medicinal usage since the sixteenth century (Drobnik and Stebel 2014, 2015). In 1600, Caspar Schwenckfeld listed six botanical names for bryophytes, which specified at least four species used as remedies in folk medicine (Drobnik and Stebel 2015). Cooper (2010) concluded that Catalogues of flora from specific European regions were published to provide local resources for the distribution and use of medicinal plants. Indigenous plants could be substituted for the exotic, often

Jacek Drobnik

drobnik@onet.pl

Adam Stebel

astebel@sum.edu.pl

1 Department of Pharmaceutical Botany, School of Pharmacy with the Division of Laboratory Medicine, Medical University of Silesia in Katowice, Ostrogórska 30, 41-200 Sosnowiec, Poland unavailable or unaffordable Materia Medica. Examples include the Harz Mountains (Thal 1588), Silesia (von Schwenckfeld 1600), Pomerania (Ölhafen 1643, 1656), and East Prussia (Loesel 1654). Since Galen's first century works listed mostly Italian medicinal plants, these books enabled local inhabitants, including pharmacists and physicians, to harvest medicinal raw materials locally (Cooper 2010). Historical medical applications of some species bryophytes listed in these catalogues correspond with today's pharmacological knowledge of the herb (Asakawa 2007; Asakawa et al. 2013; Drobnik and Stebel 2014, 2015, 2017).

Medicinal plants described in historical sources can be identified by means of a chain of synonymic botanical names (mostly pre-Linnaean), which can be cross-checked with modern knowledge of species morphology, taxonomy, phytochemistry, and ethno-pharmacology (see Drobnik and de Oliveira 2015). Information on ethno-medical and historical uses of bryophytes has been collected to target modern pharmacological research by selecting potential candidate species as medicinal plant sources (Pant 1998; Podterob and Zubets 2002; Glime 2006; Harris 2008; Bowman 2016).

Historical works have frequently provided information useful for modern medicinal therapies. For example, Adams et al. (2011) identified apparently lost Renaissance antimalarial remedies with proven antiplasmodial activity. The diuretic action of Polytrichum moss, known in seventeenth century Europe and independently used in traditional Chinese and Guatemalan medicine, was rediscovered in the nineteenth and early twentieth century (Drobnik and Stebel 2015), when Sphagnum moss was used for dressing wounds in 1882, and subsequently used in World War 1 simply as an absorbent. Medicinal use of Sphagnum peat was reported in folk 
medicine even earlier. Despite numerous biochemical studies of the multiple positive healing effects of Sphagnum, they were only finally accepted and described in the 1990s after experimental studies by the prominent British chemist, Terence J. Painter (Painter 1991, 1998, 2003; Børsheim et al.2001; Stalheim et al. 2009; Drobnik and Stebel 2017), which facilitated the effective application of sphagnan (a Sphagnum herb component) for skin and wound infections.

\section{Study Context}

While retrieving botanical data from the Cynosura Materiae medicae (Boecler 1731), we encountered a description of a medicinal stock named muscus terrestris et hortensis. Our aim was to identify one or more moss species of this stock and to compare their historical and possibly ethnopharmacological uses with modern knowledge of the species. Because no voucher material was available in any collection, we could draw on nomenclature and ecological and pharmacological data only. First, we obtained the source texts to resolve the nomenclatures. We then addressed the historical medical applications. Since the moss(es) in question were originally mentioned as styptics, we designed an experiment to measure the absorption ratio and compare it with other known medicinal mosses in order to assess whether the historical treatments for which it was used were likely to be effective.

\section{Sources}

We used two main sources for our research. The first, Cynosura materiae medicae is a multi-volume book issued, supplemented, and re-edited between 1701-1754 in Strasbourg by P. Hermann and later by J. Boecler. In the opening section, Hermann (1701) explained his choice of title, "Cynosura (Latin for "The Polar Star"), just like an aid to navigation, is to enable the reader to successfully complete his cruise on the ocean of life, by facilitating the choice of remedies." The work deals with the etymology of plant names and describes their medicinal properties. Cynosura directs special attention to little-known plants, even those already forgotten by the eighteenth century (Drobnik 2015). A second edition of Hermann's opus, already supplemented by Boecler, in 1731 contains a chapter entitled Muscus terrestris et hortensis (Boecler 1731: 444-445), entirely copied, almost word for word, from Historia Plantarum universalis (Bauhin 1651: 764), the primary source for the Cynosura.

Our second source was the Historia Plantarum Universalis, the major opus of Jean (Johann) Buahin (15411613), a Swiss botanist, was posthumously edited by J. Cherler and released in three volumes in 1650-1651. It became the most comprehensive plant encyclopaedia of the time, and was cited by botanists and pharmacists throughout the eighteenth century, including Hermann and Boecler.

\section{Material and methods}

We found reference to each botanical polynomial mentioned in Bauhin's (1651) and Boecler's (1731) texts in the first modern taxonomical monograph on mosses (Dillenius 1741). The new names that Dillenius coined and appended to these polynomials were subsequently found in a work by Hedwig (1801). We then researched the scientific binomials Hedwig established for Dillenius' polynomials in Ochyra et al.'s (2003) catalogue of moss nomenclature for their currently accepted binomials. We then cross-checked the species we had identified in this manner with the description by Bauhin (1651) in terms of their compatibility with morphologies (Table 1) and assessed their ecology (habitats, distribution, and abundance) in Europe.

Bauhin's (1651) description of the plant and medicinal usages were cross-checked with modern pharmacological data in order to confirm or question appropriateness of their medicinal uses from 1651. We also consulted the PubMed and ScienceDirect databases for ethno-pharmacological data on these species.

Absorption capabilities of the moss were measured using material from the bryological herbarium at the Department of Pharmaceutical Botany of the Medical University of Silesia in Katowice (SOSN). We used specimens of Brachythecium rutabulum (accession number: SOSN 38635), Rhytidiadelphus triquetrus (SOSN 44972), and Homalothecium sericeum (SOSN 24285). The samples were weighed at room temperature in a relative air humidity of $\sim 25 \%$.

Each sample was placed in a petri dish and rinsed with water. If the excess water was not absorbed within $15 \mathrm{~min}$, it was poured off and the fully moistened sample was reweighed. We thus calculated how much water accounted for $1 \mathrm{~g}$ of dry mass of each sample. The samples were then dried and returned to the herbarium as reference materials.

\section{Results}

\section{Original Botanical Description}

Original Latin text: Muscus terrestris et hortensis: Omnium vulgatissimus est. hic mollicellus aspergine madentibus saxis terraeque humidiori appressus repens, mollicellus ramis longis tenuibus, foliolis acuminatis costae haerentibus, colore viridi aut ex viridi flavescentibus (Bauhin 1651, p. 764).

Translation: Ground and garden moss. This mollicellus is the commonest of all on sprinkled rocks and on more humid 
ground, pressed, creeping, a long- and thin-twigged mollicellus, with acuminate leaflets, adherent with a midrib, green in color and from green to yellowish. (The Latin term mollicellus (from mollis meaning "soft") is used for "a moss.")

Additional ecological data are included in a description of economic values: Muscus qui hortos et prata humecta obsidet, ita ut gramen supprimat. Martio mense cinere aboletur, sed eo quo lixivium fuerit confectum. (That moss occupies/invades/ colonizes gardens and wet meadows, (and) therefore it suppresses the grass. In March, it is exterminated with ashes, but it is similarly extinguishable with leaches.)

\section{Nomenclature}

Boecler (1731: 444) provides four synonyms, which he copied from Bauhin (1651):

1. Muscus querno vilissimo vilior, saxis et udis terrae glebis adnascens. This name comes from a locus cited usually as Lob. Obs. p. 643, from Plantarum seu Stirpium Historia (de L'Obel 1576). The L'Obel's name is a synonym for Hypnum dentatum vulgatissimum, operculis obtusis by Dillenius (1741: 295). Dillenius' polynomial became a synonym for Hypnum rutabulum Hedw. (Hedwig 1801: 276), and the accepted name of this taxon is Brachythecium rutabulum (Hedw.) Schimp. (Ochyra et al. 2003).

2. Muscus squamosus major sive vulgaris, Tourn. I. R. H. cl. 17, f. 1. g. 1. This is correctly expressed as Muscus squamosus major sive vulgaris (Tournefort 1700: 553) and became a synonym for Hypnum vulgare triangulum maximum et pallidum (Dillenius 1741: 293). Dillenius' name is, according to Hedwig, Hypnum triquetrum Hedw. (Hedwig 1801: 256), currently Rhytidiadelphus triquetrus (Hedw.) Warnst. (Ochyra et al. 2003).

3. Muscus terrestris latioribus foliis major seu vulgaris. Raji Hist. 122. from Ray (1686, vol. 1: 122). In Dillenius' work, it became a synonym for his Hypnum dentatum vulgatissimum, operculis obtusis (1741: 295), and Hedwig established it as a binomial, Hypnum rutabulum Hedw. (1801: 276), today, it is Brachythecium rutabulum (Hedw.) Schimp. (Ochyra et al. 2003).

4. Muscus terrestris et hortensis, I. B. 3. 764. comes from a citation from Bauhin (1651, vol. 3: 764). It became a synonym for Hypnum vulgare sericeum recurvum capsulis erectis cuspidatis (Dillenius 1741: 323). Dillenius' name is Leskea sericea Hedw., according to Hedwig (1801: 228); the name has since changed to Homalothecium sericeum (Hedw.) Schimp. (Ochyra et al. 2003).

Stokes (1812) was the only author after Boecler (1731) (and probably the only nineteenth century Materia Medica writer) who used some these names. He filed two species: a)
Muscus terrestris latioribus foliis major seu vulgaris. Raji Hist. 122 he considered to be Hypnum triquetrum (Stoke's mistake), and b) Hypnum vulgare sericeum recurvum capsulis erectis cuspidatis he listed for Leskea sericea (correct identification).

\section{Original Medicinal Uses}

Bauhin (1651) and Boecler (1731) reported the following usage: Empirici hoc musco uti Joh. Bauhinus loquitur ad sistendum sanguinem utuntur, ab Ursis admoniti: hi enim quamprimum vulnerati sunt, eo sanguinem sistunt. (Practitioners use this moss, according to Joh. Bauhin, for stemming the blood, learned from bears, which, whenever hurt, use them to stop blood.)

\section{Absorption Capabilities}

One g of air-dried moss herb Brachythecium rutabulum absorbed an average of $16.1 \mathrm{~g}$ of water, Rhytidiadelphus triquetrus $10.8 \mathrm{~g}$, and Homalothecium sericeum $11.7 \mathrm{~g}$.

\section{Discussion}

\section{Habitats, Ecology, and Nomenclature}

To assess the accuracy of the historical descriptions, modern data are quoted (but see Table 1).

Brachythecium rutabulum (Hedw.) Schimp. (Fig. 1) is a large moss, growing in lax, glossy, bright green or yellowish green tufts or patches. It is common in Europe and occurs in many habitats, such as soil (both in woodland and nonforest vegetation), tree boles, logs, stones, and walls (Frey et al. 2006). This species is frequently found in man-made habitats such as lawns in gardens, where it is regarded as an unwanted plant.

Rhytidiadelphus triquetrus (Hedw.) Warnst. (Fig. 2) is a very robust moss, forming green, whitish green, or yellowish green tufts or patches. It grows mainly on terricolous habitats in woodlands and thickets, and is common in Europe (Frey et al. 2006).

Homalothecium sericeum (Hedw.) Schimp. (Fig. 3) is moderately robust, glossy, yellowish green to golden brown, occurring in dense rough mats or patches, mainly on bark of trees and on bare rocks. Sometimes it grows on man-made habitats such as walls and roofs, and it is common in Europe (Frey et al. 2006).

Two pieces of information in Bauhin (1651) do not match: the statement that moss is terrestrial and that it can also occur on rocks sprinkled with water. In botany the Latin term terrestris traditionally refers to "growing on soil, on ground," and in modern plant ecology this habitat is termed terricolous; 
Table 1 Comparison of characteristics of identified moss species with the original description of muscus terrestris et hortensis

\begin{tabular}{|c|c|c|c|c|}
\hline \multicolumn{2}{|c|}{$\begin{array}{l}\text { Characters of muscus terrestris et hortensis } \\
\text { from the Bauhin's (1651) and Boecler's (1731) } \\
\text { descriptions }\end{array}$} & \multirow[t]{2}{*}{ Brachythecium rutabulum } & \multirow{2}{*}{$\begin{array}{l}\text { Rhytidiadelphus } \\
\text { triquetrus } \\
\text { now only regionally }\end{array}$} & Homalothecium sericeum \\
\hline \multirow[t]{5}{*}{$\begin{array}{l}\text { Distribution } \\
\text { and ecology }\end{array}$} & $\begin{array}{l}\text { The commonest of all }[\ldots] \text {, } \\
\text { found everywhere }\end{array}$ & & & now only regionally \\
\hline & on sprinkled rocks & it can occur & it can grow but sporadically & frequent on rocks but on dry ones \\
\hline & on more humid ground & usually so & usually so & on dry rocks and tree trunks \\
\hline & it occupies/invades gardens & true, frequently & rather a forest species & rather not unless as an epiphyte \\
\hline & $\begin{array}{l}\text { [it] occupies/invades/colonizes } \\
{[\ldots] \text { wet meadows }}\end{array}$ & true & rather not & false \\
\hline \multirow[t]{5}{*}{ Morphology } & pressed, creeping & $\begin{array}{l}\text { yes (also presenting other } \\
\text { growth forms) }\end{array}$ & rather erect & true \\
\hline & long- and thin-twigged & true & false, twigs are thick & false, twigs are thin but also short \\
\hline & leaflets acuminate & true & rather not & acuminate to aristate \\
\hline & $\begin{array}{l}\text { [leaflets] adherent to/with } \\
\text { a midrib }\end{array}$ & \multicolumn{3}{|c|}{$\begin{array}{l}\text { A leaf midrib (Latin: costa) in mosses is a microscopic structure, hardly visible without magnifying } \\
\text { equipment. This morphological term is missing still in Dale (1737). Maybe whole arch-shaped moss } \\
\text { stems were termed "ribs" here. }\end{array}$} \\
\hline & $\begin{array}{l}\text { [leaflets] green in colour } \\
\text { and from green to yellowish }\end{array}$ & true & rather green to whitish-green & true \\
\hline
\end{tabular}

a moss growing on rocks it is saxicolous (Latin: saxatilis or saxicola). Among the identified species, Brachythecium rutabulum and Rhytidiadelphus triquetrus are terricolous matching the description muscus terrestris et hortensis (a terrestrial and garden moss). In gardens, we should expect wet stones rather than rocky outcrops. However, compared with the other two species, B. rutabulum can grow on stones and it can colonize a wider range of habitats, including man-made habitats (Dierßen 2001). Homalothecium sericeum grows almost exclusively on tree bark or dry rock outcrops, and $R h$. triquetrus grows mainly on the forest floor.

Regarding distribution and ecology, Boecler (1731) added the comment, ubivis notus ("seen everywhere"), which signifies a very common species. That this comment was added 80 years after J. Bauhin's work leads us to assume it originated

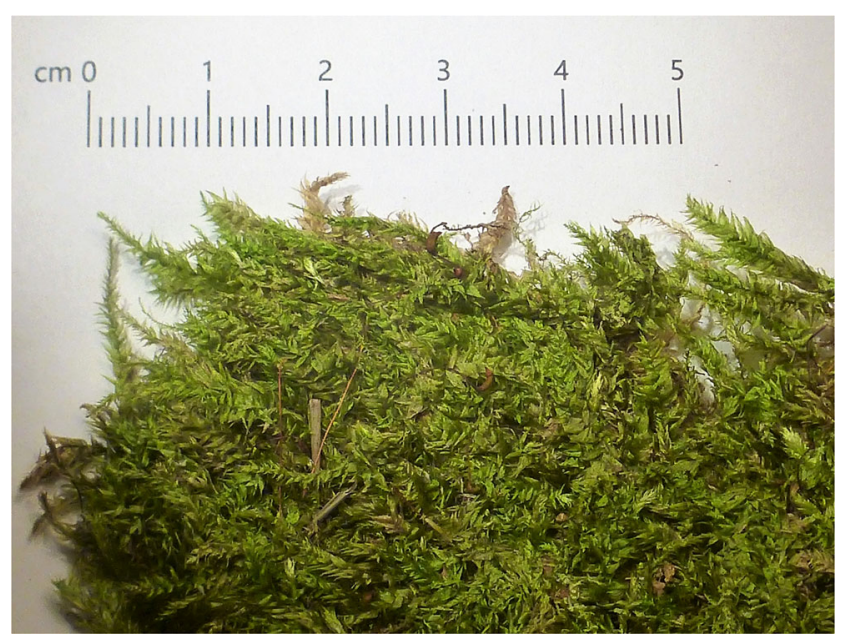

Fig. 1 Dry Brachythecium rutabulum as a dressing material from either a herbalist's experience (on harvesting herbal material) or perhaps only a wildlife observation. We should also note that at that time, all three mosses could be found either more or less frequently than currently.

J. Bauhin's remark on weed control of moss and reference to its name, muscus terrestris et hortensis, suggests that it was a common species known by gardeners. A distinctive plant known from man-made habitats must have been named for practical purposes. Such a garden weed would most probably have been Brachythecium rutabulum, because this species is frequent in gardens today and is controlled by soil liming. In the past, this would have been accomplished with ashes or potash, well-known and readily available alkaline substances.

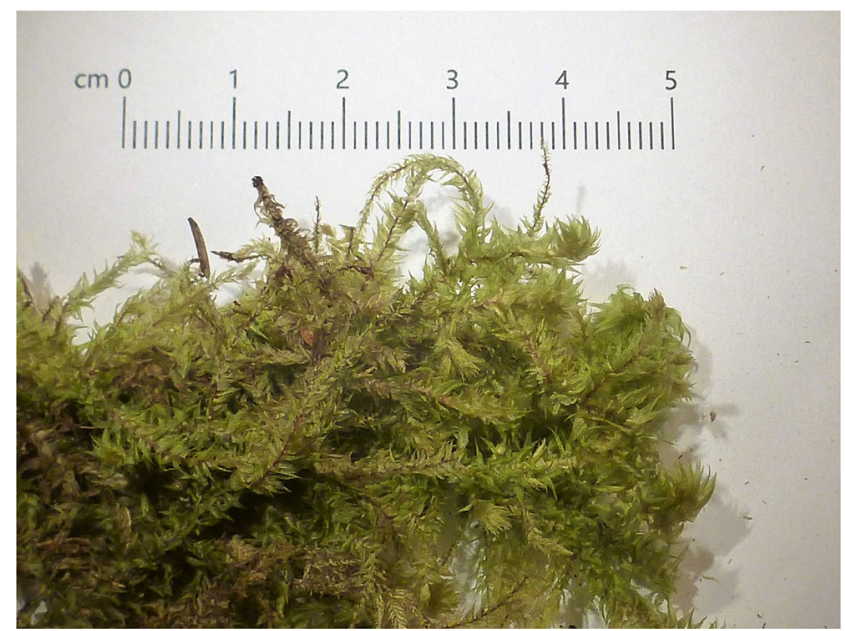

Fig. 2 Dry Rhytidiadelphus triquetrus as a dressing material 


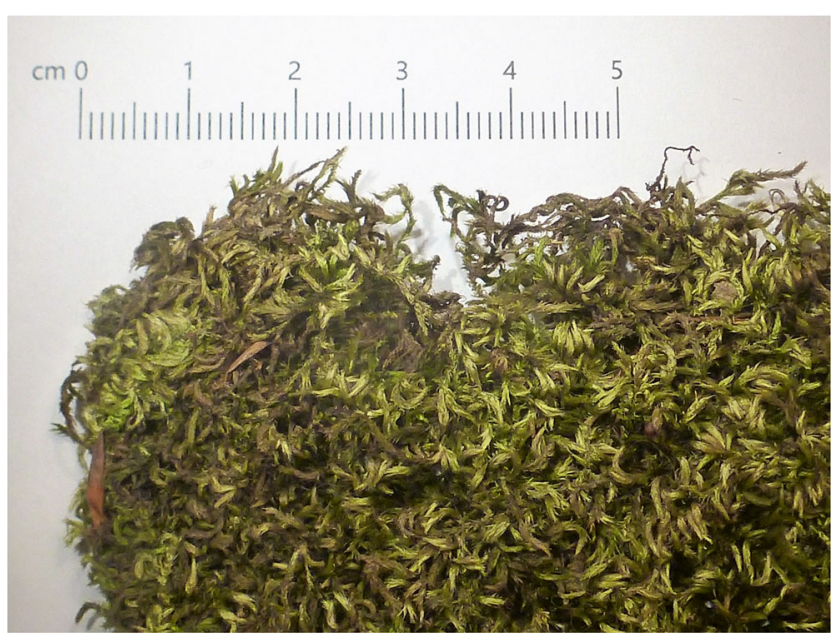

Fig. 3 Dry Homalothecium sericeum as a dressing material

A list of polynomials (Table 2) shows nomenclatural changes between 1576 and 1801 for the species under discussion. Botanical names used by different botanists were frequently given synonyms (as depicting the same species) much later by younger botanists. In our case, J. Bauhin cited four botanical names, and thus we resolve his nomenclature in our text above. Any botanist could also reject some of the known names as uncertain. Almost 200 years after J. Bauhin, the prominent bryologist Dillenius collected and critically arranged all known bryological names (Table 2), and it is notable that some authors both before and after J. Bauhin mention certain species under even more synonyms.

We can see that names no. 5-7 cited in Bauhin (1651), of which at least the seventh indicates Sphagnum, were excluded from synonyms by Ray (1686) and Tournefort (1700). This is illustrated from the woodcut in L'Obel (1591, vol. 2: 242), which presented a plant subtitled muscus terrestris vulgaris (name 7, Table 2). It had clavate (club-shaped), and densely foliate stems (Fig. 4), and highly resembles Lycopodium clavatum L., which in pharmacology was called muscus terrestris, similar to muscus terrestris et hortensis (Bauhin 1651), but originating from another name for L. clavatum, muscus terrestris repens seu calvatus (Bauhin 1623). On closer inspection, in de L'Obel (1591) woodcut, the tops of three stems reveal short pseudopodia with sporangia, typical for Sphagnum mosses. Ray (1686) might have noticed them and thus he no longer considered names 5, 6, and 7 synonyms for names 1, 2, 3 and 4. A herbal stock with a single known medical application (styptic) was given a scientific botanical name, muscus terrestris et hortensis, suggesting that this herb was named intentionally.

Based on the above discussion, we propose that the identification of Muscus terrestris seu hortensis I. B as Homalothecium sericeum as proposed by Dillenius (1741) should be considered the least probable. Moreover, the remaining synonyms (used by J. Bauhin and Ray) are identified as B. rutabulum or Rh. triquetrus. J. Bauhin wrote clearly (and Boecler repeated) that Muscus terrestris et hortensis is the commonest of all terricolous mosses, and Boecler added, "met everywhere." The Latin name confirms the habitat. We should also note that in the seventeenth and eighteenth century rocky habitats were reflected in plant names by means of the adjectives saxatilis or petraeus, and stones by lapideus.

Another argument against $H$. sericeum is that Brachythecium rutabulum scored the highest absorption rate (Table 1). Rh. triquetrus, in second place, grows in forests but it can also be found in gardens as an ornamental. However, there are no seventeenth or eighteenth century accounts of $R h$. triquetrus as an ornamental in Europe (Drobnik et al. 2016). Thus we conclude that muscus terrestris et hortensis is the common terrestrial moss Brachythecium rutabulum, although the lack of any seventeenth or eighteenth century herbarium references makes this identification a well-substantiated proposal rather than a proof.

\section{Brachythecium rutabulum: A Medicinal Moss}

The differences in the water absorption ratio among the three investigated moss species result from the spatial structure of their cushions, with B. rutabulum being visibly the densest. Having collected data on seventeenth century uses, we assessed which of the three species is a more effective dressing for wounds, and concluded that the high absorption capacity of $B$. rutabulum make this species the most useful and easily available of all three discussed. While the Latin term, stypticum (blood-stemming) was understood in the eighteenth century as describing "stopping externally the blood outflow" (de Kinder and de Wint 1719: 14), in contemporary English the word styptic refers to the pharmacological effects of tannins; however, tannins never occur in mosses.

The absorption capacity of dry B. rutabulum, (16.1:1), is approximately $75 \%$ as effective as that of Sphagnum, which, according to Porter (1917), can absorb an average of $20 \mathrm{~g}$ of water per $1 \mathrm{~g}$ of herb. The antibacterial properties of $B$. rutabulum extracts have been recently reported by Singh et al. (2007), and their use has been reported in the Himalayas (Pant et al. 1986).

Wound dressings made of Sphagnum were developed in Germany in 1882 (Drobnik and Stebel 2017), but German articles "were not republished or even abstracted in English until after the (First World) war began [...]" (Porter 1917). Both J. Bauhin (1651) and J. Boecler (1731) wrote about Brachythecium rutabulum, providing examples of the use of such moss dressings predating the use of Sphagnum in Germany by 231 years, and by some 263 years in England and the USA (Porter 1917).

This history would seem indicate moss dressings of the mid-seventeenth century are forgotten prototypes of Sphagnum dressings in World War I, and their absorptive 


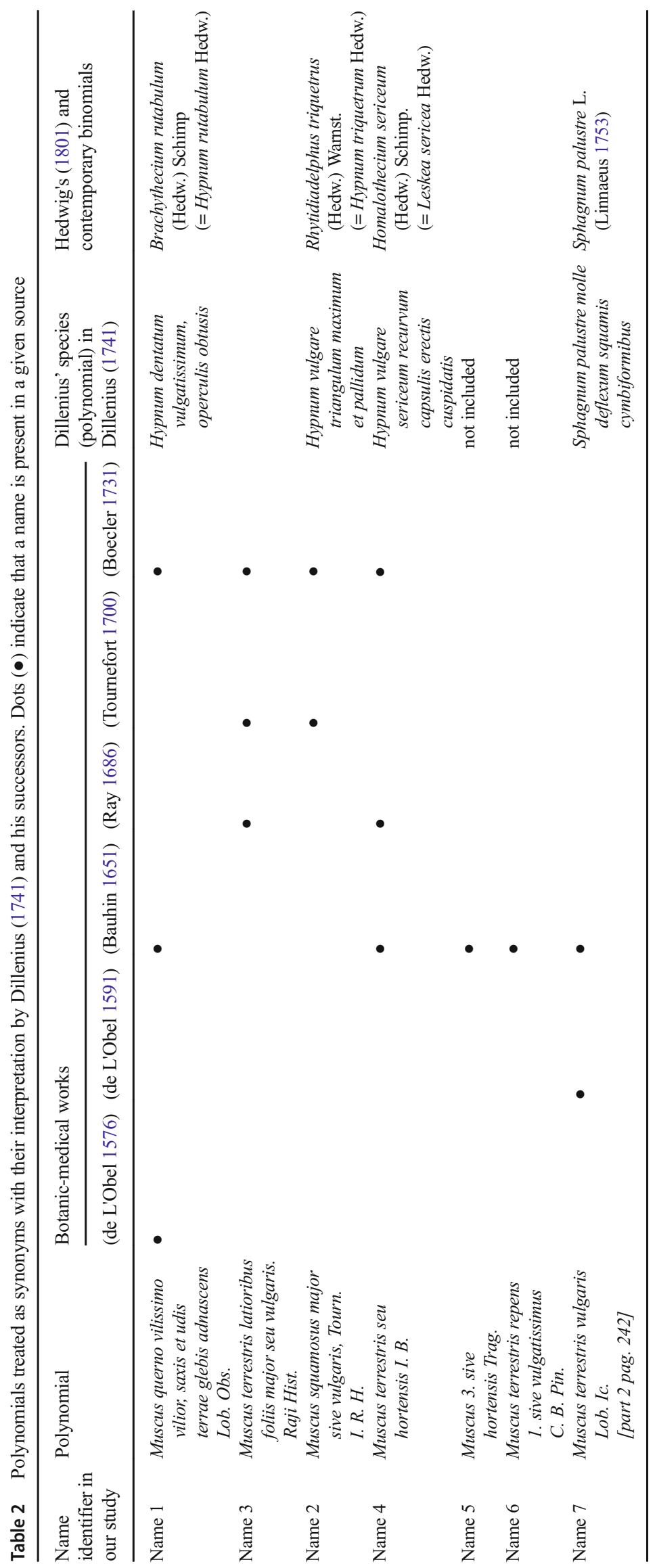


Fig. 4 Muscus terrestris vulgaris (de L'Obel 1591, part 2, page

242). No description exists in the respective text-book which is de L'Obel (1576)

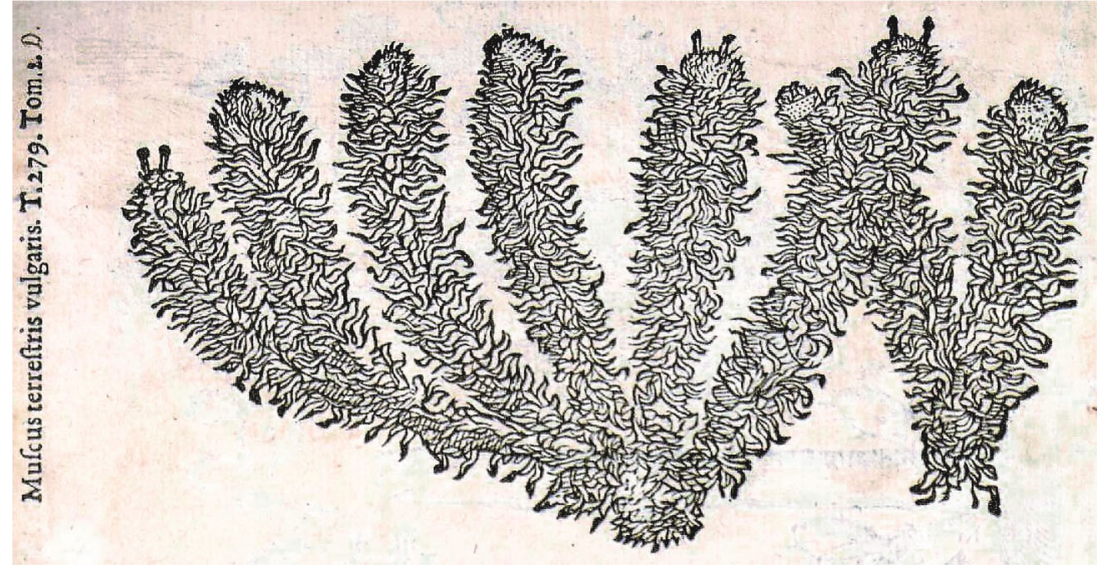

1651 are most consistent with the ecology and morphology of this species. Based on its ecology and structure, it was a possible dressing material in seventeenth century Europe.

The spatial structure of $B$. rutabulum defines its physical properties and substantiates its historical use against bleeding. However, because the antimicrobial or anti-inflammatory activities have been confirmed in topical uses of both these and other mosses, the pharmacology of B. rutabulum-based dressings (or B. rutabulum-derived topical drugs) requires additional experimental studies.

Funding This study was funded by the Medical University of Silesia in Katowice grant (grant No. KNW-640-2-1-343/17), which supported the editing process.

\section{Compliance with Ethical Standards}

Conflict of Interest The authors declare no potential conflict of interest. The nature of this research did not require informed consent.

Open Access This article is distributed under the terms of the Creative Commons Attribution 4.0 International License (http:// creativecommons.org/licenses/by/4.0/), which permits unrestricted use, distribution, and reproduction in any medium, provided you give appropriate credit to the original author(s) and the source, provide a link to the Creative Commons license, and indicate if changes were made.

\section{Conclusions}

We draw two main conclusions from this study:

1. The seventeenth century botanical name, Muscus terrestris et hortensis, refers to Brachythecium rutabulum, and thus it can be assumed that Brachythecium rutabulum dressings could have been used long before 1882, when Sphagnum was reported as used in Germany for the same purpose.

2. Based on the three species we examined in this study, the common moss Brachythecium rutabulum showed the highest absorption capacity for water. Descriptions from

\section{References}

Adams M., Gschwind S., Zimmermann S., Kaiser M., and Hamburger M. (2011). Renaissance remedies: Antiplasmodial protostane triterpenoids from Alisma plantago-aquatica L. (Alismataceae). Journal of Ethnopharmacology 135: 43-47. https://doi.org/10. 1016/j.jep.2011.02.026.

Ahmed E., Elkhateeb W., Taie H., Rateb M., and Fayad W. (2017). Biological capacity and chemical composition of secondary metabolites from representatives Japanese lichens. Journal of Applied Pharmaceutical Science: 98-103. https://doi.org/10.7324/JAPS. 2017.70113 . 
Asakawa Y. (2007). Biologically active compounds from bryophytes. Pure and Applied Chemistry 79: 557-580. https://doi.org/10.1351/ pac200779040557.

Asakawa Y., Ludwiczuk A., and Hashimoto T. (2013). Cytotoxic and antiviral compounds from bryophytes and inedible fungi. Journal of Pre-Clinical and Clinical Research 7: 73-85.

Bauhin, C., (1623). Пív $\alpha \xi$ Theatri botanici... Sumptibus \& typis Ludovici Regis, Basileae. https://doi.org/10.5962/bhl.title.712

Bauhin, J., (1651). Historia plantarum universalis nova et absolutissima cum consensu et dissensu circa eas. Ebroduni.

Boecler, J., (1731). Cynosurae materiae medicae continuatio secunda. Sumptibus Johannis Beckii, Argentorati.

Børsheim, K. Y., Christensen, B. E., Painter, T. J. (2001). Preservation of fish by embedment in Sphagnum moss, peat or holocellulose: experimental proof of the oxopolysaccharidic nature of the preservative substance and of its antimicrobial and tanning action. Innovative Food Science \& Emerging Technologies 2(1): 63-74.

Bowman J. L. (2016). A brief history of Marchantia from Greece to genomics. Plant and Cell Physiology 57: 210-229. https://doi.org/ $10.1093 / \mathrm{pcp} / \mathrm{pcv} 044$

Çolak E., Kara R., Tülay E., Çelik G. Y., and Elibol B. (2011). Investigation of antimicrobial activity of some Turkish pleurocarpic mosses. African Journal of Biotechnology 10: 12905-12908. https://doi.org/10.5897/AJB11.1126.

Cooper, A., (2010). Inventing the indigenous. Local knowledge and natural history in early modern Europe. Cambidge University Press, Cambridge.

Costa-Neto E. M. (2002). The use of insects in folk medicine in the state of Bahia, northeastern Brazil, with notes on insects reported elsewhere in Brazilian folk medicine. Human Ecology 30(2): 245-263.

Dale, S., (1737). Pharmacologia seu Manuductio ad Materiam medicam, 3rd ed. Impensis Gul. Innys \& Ric. Manby, Regiae Societati Typographorum, Londini.

Dierßen, K., (2001). Distribution, ecological amplitude and phytosociological characterization of European bryophytes, Bryophytorum Bibliotheca. J. Cramer in der gebrüder Borntraeger Verlagsbuchhandlung, Berlin, Stuttgart.

Dillenius, J.J., (1741). Historia muscorum in qua circiter sexcentae Species veteres et novae ad sua Genera relatae describuntur. e Theatro Sheldoniano, Oxonii. https://doi.org/10.5962/bhl.title. 82186

Drobnik, J., (2015). Roślinna materia medyczna (1700-1950) pod względem taksonomii, nomenklatury i terminologii łacińskiej aptecznej i farmakognostycznej. Materia medica vegetabilis (1700-1950) secundum Taxonomiam ac Nomenclaturam et Terminologiam Latinam officinalem et pharmacognosticam. Śląski Uniwersytet Medyczny w Katowicach, Katowice.

Drobnik J., and de Oliveira A. (2015). Cissus verticillata (L.) Nicolson \& C.E. Jarvis (Vitaceae): Its identification and usage in the sources from 16th to 19th century. Journal of Ethnopharmacology 171: 317-329. https://doi.org/10.1016/j.jep.2015.06.003.

Drobnik J., and Stebel A. (2014). Medicinal mosses in pre-Linnaean bryophyte floras of central Europe. An example from the natural history of Poland. Journal of Ethnopharmacology 153: 682-685. https://doi.org/10.1016/j.jep.2014.03.025.

Drobnik J., and Stebel A. (2015). Central European medicinal bryophytes in the 16th-century work by Caspar Schwenckfeld, and their ethnopharmacological origin. Journal of Ethnopharmacology 175: 407-411. https://doi.org/10.1016/j.jep.2015.09.033.

Drobnik J., and Stebel A. (2017). Tangled history of the European uses of Sphagnum moss and sphagnol. Journal of Ethnopharmacology 209: 41-49. https://doi.org/10.1016/j.jep.2017.07.025.

Drobnik J., Stebel A., and Ochyra R. (2016). The earliest bryological data from east-Central Europe. Annales Botanici Fennici 53(5-6): 383400. https://doi.org/10.5735/085.053.0610.
Ertürk Ö., Sahin H., Ertürk E. Y., Hotaman H. E., Koz B., and Özdemir Ö. (2015). The antimicrobial and antioxidant activities of extracts obtained from some moss species in Turkey. Herba Polonica 61(4): 52-65. https://doi.org/10.1515/hepo-2015-0031.

Frey, W., Frahm, J.-P., Fischer, E., Lobin, W., (2006). The liverworts, mosses and ferns of Europe. Harley Books, Colchester.

Glime, J.M., (2006). Uses, in: Bryophyte ecology. E-book sponsored by Michigan Technological University and the International Association of Bryologists. published online at http://www. bryoecol.mtu.edu/.

Harris E. S. J. (2008). Ethnobryology: Traditional uses and folk classification of bryophytes. The Bryologist 111: 169-217. https://doi.org/ 10.1639/0007-2745(2008)111[169:ETUAFC]2.0.CO;2.

Hedwig, J., (1801). Species muscorum frondosorum. Sumtu Joannis Ambrosii Barthii et Parisiis, Amand Koenig, Lipsiae. https://doi. org/10.5962/bhl.title.26

Hermann, P., (1701). Cynosura Materiae medicae. Typis et sumptibus Joh. Frid. Spoor, Argentorati.

de Kinder, J., de Wint, G.F., (1719). Nucleus Belgicus materiae medicae. Typis Simonis t'Serstevens, Bruxellis.

Klavina L., Springe G., Nikolajeva V., Martsinkevich I., Nakurte I., Dzabijeva D., and Steinberga I. (2015). Chemical composition analysis, antimicrobial activity and cytotoxicity screening of Moss extracts (Moss Phytochemistry). Molecules 20: 17221-17243. https:// doi.org/10.3390/molecules200917221.

Linnaeus, C., (1753). Species Plantarum. Impensis Laurentii Salvii, Holmiae. https://doi.org/10.5962/bhl.title.669

L'Obel, M. de, (1576). Plantarum seu stirpium historia. Ex officina Christophori Plantini Architypographi, Antverpiae. https://doi.org/ 10.5962/bhl.title.7094

L'Obel, M. de, (1591). Icones Stirpium seu Plantarum tam exoticarum, quam indigenarum in gratiam rei herbariae Studiosorum in duas partes digestae cum septem linguarum indicibus, ad diversarum nationum usum, 2nd ed. ex Officina Plantiniana, apud Viduam et Joannem Moretum, Antverpiae. https://doi.org/10.5962/bhl.title. 9308

Loesel, J., (1654). Plantae in Borussia sponte nascentes emanu scripto parentis mei divulgo Johannes Loeselius, Johannis filius. Typis Paschalii Mensenii, Regiomonti Borussorum.

Ochyra, R., Żarnowiec, J., Bednarek-Ochyra, H., (2003). Census catalogue of polish mosses, biodiversity of Poland. Polish Academy of Sciences, Kraków.

Ölhafen, N., (1643). Elenchus Plantarum circa Nobile Borussorum Dantiscum sua sponte nascentium, earundem Synonyma Latina et Germanica, Loca natalitia, Florum tempora \& Vires exhibens. impensis Georgi Rheti, Dantisci.

Ölhafen, N., (1656). Elenchus Plantarum circa Nobile Borussorum Dantiscum sua sponte nascentium cum Synonyma earundem Latina et Germanica, Indice Autorum, Locis natalibus, Florum Temporibus et Viribus, denuo recensitus ac locupletatus a Successore ejus, de quo in Praefatione, 2nd ed. L. Eichstaedt, G. Rhete, Dantisci.

Oztopcu-Vatan P., Savaroglu F., Filik-Iscen C., Kabadere S., Ilhan S., and Uyar R. (2011). Antimicrobial and antiproliferative activities of Homalothecium Sericeum (Hedw.) Schimp. Extracts. Fresenius Environmental Bulletin 2a: 461-466.

Painter, T. J. (1991). Lindow man, tollund man and other peat-bog bodies: The preservative and antimicrobial action of Sphagnan, a reactive glycuronoglycan with tanning and sequestering properties. Carbohydrate Polymers 15(2): 123-142.

Painter, T. J. (1998). Carbohydrate polymers in food preservation: an integrated view of the Maillard reaction with special reference to discoveries of preserved foods in Sphagnum-dominated peat bogs. Carbohydrate Polymers 36(4): 335-347. 
Painter, T. J. (2003). Concerning the wound-healing properties of Sphagnum holocellulose: the Maillard reaction in pharmacology. Journal of Ethnopharmacology 88(2-3): 145-148.

Pant, G., (1998). Medicinal uses of bryophytes, In: Chopra, R.N. (Ed.), Topics in bryology. Allied publishers 1td., new Dehli (and others), pp. $112-124$.

Pant G., Tewari S. D., Pargaien M. C., and Bisht L. S. (1986). Bryological activities in north-west Himalaya-II. A bryophyte foray in the ascot region of district Pithoragarh (Kumaun Himalayas). The Bryological Times 39: 2-3.

Podterob A. P., and Zubets E. V. (2002). A history of the medicinal use of plants of the genus sphagnum. Pharmaceutical Chemistry Journal 36: 27-29. https://doi.org/10.1023/A:1019884605441.

Porter J. B. (1917). Sphagnum moss for use as a surgical dressing; its collection, preparation and other details. The Canadian Medical Association Journal 7: 201-207.

Ray, J., (1686). Historia Plantarum generalis. Tomus primus. Samuel Smith \& Benjamin Walford, Londini.

Schwenckfeld, C. von, (1600). Stirpium et Fossilium Silesiae Catalogus in quo praeter etymon, Natales, tempus, Natura et vires cum variis Experimentis assignatur... impensis Davidis Alberti, Lipsiae.

Singh M., Rawat A. K. S., and Govindarajan R. (2007). Antimicrobial activity of some Indian mosses. Fitoterapia $78:$ 156-158. https://doi. $\operatorname{org} / 10.1016 /$ j.fitote.2006.10.008.
Stalheim T., Ballance S., Christensen B. E., and Granum P. E. (2009). Sphagnan - A pectin-like polymer isolated from Sphagnum moss can inhibit the growth of some typical food spoilage and food poisoning bacteria by lowering the $\mathrm{pH}$. Journal of Applied Microbiology 106: 967-976. https://doi.org/10.1111/j.1365-2672. 2008.04057.x.

Staub P. O., Casu L., and Leonti M. (2016). Back to the roots: A quantitative survey of herbal drugs in Dioscorides' de Materia Medica (ex Matthioli, 1568). Phytomedicine 23: 1043-1052. https://doi.org/10. 1016/j.phymed.2016.06.016.

Stebel A., Smolarz H. D., Jankowska-Błaszczuk M., Trylowski M., and Bogucka-Kocka M. (2016). Seasonal variation in antioxidant activity of selected mosses from Poland. Fragmenta Naturae 49: 65-73.

Stokes, J., (1812). A botanical Materia Medica: Consisting of the generic and specific characters of the plants used in medicine and diet, with synonyms, and references to medical authors, vol. 4. J. Johnson \& Co., London.

Thal, I., (1588). Sylva Hercynia, sive Catalogus Plantarum sponte nascentium in Montibus, et Locis vicinis Hercyniae, quae respicit Saxoniam, conscriptus singulari studio. Apud Iohannem Feyerabend, Francofurti ad Moenum. https://doi.org/10.5962/bhl. title. 128839

Tournefort J. P. (1700). Institutiones Rei herbariae. Typographia Regia, Parisiis. https://doi.org/10.5962/bhl.title.713. 